\title{
THE SERUM PROTEINS AT 6 MONTHS OF AGE IN INFANTS FED ON HUMAN OR COW'S MILK OR ON BOTH
}

\author{
BY \\ FATMA HASSAN and MAVIS GUNTHER \\ From the Department of Child Welfare, University College Hospital, London
}

(RECEIVED FOR PUBLICATION JULY 19, 1957)

The finding by Douglas (1950) that breast-fed babies possess an immunity to measles which bottlefed babies do not, and the fact that the administration of $\gamma$ globulin can protect a baby from the infection, suggested that babies receiving human milk might have a greater serum $\gamma$ globulin content than those giving cow's milk from a bottle. In a serological investigation of neonatal antibodies Boorman, Dodd and Gunther (1958) could detect no increase in the baby's circulating $\mathrm{Rh}$ antibodies as a result of feeding high-titre serum; nor could they find any effect on serum isoagglutinins from the consumption of colostrum and milk of varying titres of anti-A and anti-B agglutinins which the babies received from their mothers. It seemed possible, however, that $\gamma$ globulins were more readily absorbed or rebuilt, even though they might lose their particular immunological specificity, from human rather than bovine globulins taken by mouth. The absorption of serum proteins of the animal's own species and not of others has been suggested by Dent and Schilling (1948) from their work on dogs. Although the total quantity of $\gamma$ globulin needed to alter a baby's susceptibility to measles is small, it seemed worth while to see whether a detectable difference in the serum proteins was produced over a period of months by different methods of feeding.

\section{Present Investigation}

In the investigation here reported comparison was made of the serum from babies who were known to

have received only one kind of milk, human or bovine, from birth or a mixture of both. By 6 months of age they had, however, all received other foods in small quantities. The total protein in the serum at 6 months of age was estimated by the density method of Linderstrøm-Lang and Lanz (1938) as modified by Lowry and Hunter (1945). The serum was subjected to electrophoresis on a paper strip (Flynn and de Mayo, 1951) and the components were estimated by a scanner and direct transmission of light (Crook, Harris and Warren, 1952).

\section{Results}

The sera from the three groups of infants, receiving (a) breast milk, $(b)$ cow's milk or (c) a mixture of human and cow's milk, showed no significant differences in their content of total protein and none in the content of the components of albumin and of $\alpha_{1}, \alpha_{2}, \beta$ and $\gamma$ globulin (see Table ).

It is concluded that no differences in the serum protein levels resulting from feeding the infants with human or cow's milk could be detected in the samples by micro-electrophoretic analysis.

Our best thanks go to Professor F. L. Warren and to Dr. N. R. Butler for their help.

\section{REFERENCES}

Boorman, K. E., Dodd, B. E. and Gunther, M. (1958). Arch. Dis. Childh., 33, 24.

Crook, E. M., Harris, H. and Warren, F. L. (1952). Biochem. J., 51, xxvi.

Dent, C. E. and Schilling, J. A. (1948). Ibid., 42, xxix.

Douglas, J. W. B. (1950). J. Obstet. Gynaec. Brit. Emp., 57, 335

Flynn, F. V. and de Mayo, P. (1951). Lancet, 2, 235.

Linderstrøm-Lang, K. and Lanz, H. (1938). C.R. Lab. Carlsberg (Ser. chim.), 21, 315. (No. 24).

Lowry, O. H. and Hunter, T. H. (1945). J. biol. Chem., 159, 465. TABLE

SERUM PROTEINS OF BABIES AT 6 MONTHS FED WITH HUMAN OR COW'S MILK OR A MIXTURE OF BOTH

\begin{tabular}{|c|c|c|c|c|c|c|c|c|c|c|c|c|c|c|}
\hline \multirow{3}{*}{$\begin{array}{l}\text { Feeding } \\
\text { Breast }\end{array}$} & \multirow{3}{*}{$\begin{array}{c}\begin{array}{c}\text { No. } \\
\text { of } \\
\text { Cases }\end{array} \\
11\end{array}$} & \multirow{3}{*}{$\begin{array}{c}\begin{array}{c}\text { Mean } \\
\text { Birth } \\
\text { Weight } \\
\text { (g.) }\end{array} \\
3,400\end{array}$} & \multirow{2}{*}{\multicolumn{2}{|c|}{$\begin{array}{c}\text { Total } \\
\text { Protein } \\
\text { (g. } / 100 \mathrm{ml} .)\end{array}$}} & \multicolumn{2}{|c|}{$\underset{\%}{\text { Albumin }}$} & \multicolumn{2}{|c|}{$\alpha_{\mathbf{I}}{\underset{\%}{\text { Globulin }}}$} & \multicolumn{2}{|c|}{$\alpha_{\alpha_{2}}$ Globulin } & \multicolumn{2}{|c|}{$\beta$ Globulin } & \multicolumn{2}{|c|}{$\gamma$ Globulin } \\
\hline & & & & & Rel. & Absol. & Rel. & Absol. & Rel. & Absol. & Rel. & Absol. & Rel. & Absol. \\
\hline & & & $\begin{array}{l}\text { Mean } \\
\text { S.D. }\end{array}$ & $\begin{array}{l}6 \cdot 42 \\
0 \cdot 55\end{array}$ & $\begin{array}{r}64 \cdot 56 \\
3 \cdot 69\end{array}$ & $\begin{array}{l}4 \cdot 16 \\
0 \cdot 55\end{array}$ & $\begin{array}{l}4 \cdot 61 \\
0.95\end{array}$ & $\begin{array}{l}0 \cdot 293 \\
0 \cdot 048\end{array}$ & $\begin{array}{r}10 \cdot 12 \\
2 \cdot 43\end{array}$ & $\begin{array}{l}0 \cdot 64 \\
0 \cdot 14\end{array}$ & $\begin{array}{r}12 \cdot 87 \\
1 \cdot 89\end{array}$ & $\begin{array}{l}0 \cdot 82 \\
0 \cdot 13\end{array}$ & $\begin{array}{l}7 \cdot 64 \\
2 \cdot 59\end{array}$ & $\begin{array}{l}0 \cdot 48 \\
0 \cdot 127\end{array}$ \\
\hline Bottle & 6 & 3,515 & $\begin{array}{l}\text { Mean } \\
\text { S.D. }\end{array}$ & $\begin{array}{l}6 \cdot 37 \\
0 \cdot 57\end{array}$ & $\begin{array}{c}65 \cdot 1 \\
2 \cdot 38\end{array}$ & $\begin{array}{l}4 \cdot 15 \\
0 \cdot 34\end{array}$ & $\begin{array}{l}5.42 \\
0.69\end{array}$ & $\begin{array}{l}0.41 \\
0.073\end{array}$ & $\begin{array}{r}10 \cdot 01 \\
1 \cdot 28\end{array}$ & $\begin{array}{l}0.64 \\
0.097\end{array}$ & $\begin{array}{r}11 \cdot 75 \\
2 \cdot 24\end{array}$ & $\begin{array}{l}0.72 \\
0.09\end{array}$ & $\begin{array}{l}7 \cdot 74 \\
2 \cdot 52\end{array}$ & $\begin{array}{l}0 \cdot 49 \\
0 \cdot 19\end{array}$ \\
\hline Mixed & 11 & 3,285 & $\begin{array}{l}\text { Mean } \\
\text { S.D. }\end{array}$ & $\begin{array}{l}6 \cdot 16 \\
0 \cdot 47\end{array}$ & $\begin{array}{c}62 \cdot 5 \\
4 \cdot 24\end{array}$ & $\begin{array}{l}3.79 \\
0.91\end{array}$ & $\begin{array}{l}5 \cdot 58 \\
1 \cdot 32\end{array}$ & $\begin{array}{l}0 \cdot 34 \\
0 \cdot 073\end{array}$ & $\begin{array}{r}10.91 \\
1.66\end{array}$ & $\begin{array}{l}0 \cdot 67 \\
0 \cdot 117\end{array}$ & $\begin{array}{r}13 \cdot 25 \\
1 \cdot 64\end{array}$ & $\begin{array}{l}0.81 \\
0.085\end{array}$ & $\begin{array}{l}7 \cdot 80 \\
1 \cdot 92\end{array}$ & $\begin{array}{l}0.48 \\
0.12\end{array}$ \\
\hline
\end{tabular}

